\title{
Erratum
}

Cold Spring Harb Symp Quant Biol 83 (2018) doi: 10.1101/sqb.2018.83.038174

\section{Erratum: Investigating the Therapeutic Mechanism of Cannabidiol in a Human Induced Pluripotent Stem Cell (iPSC)-Based Model of Dravet Syndrome}

\author{
Yishan Sun and Ricardo E. Dolmetsch
}

The title of this article was originally "Investigating the Therapeutic Mechanism of Cannabidiol in a Human Induced Pluripotent Stem Call (iPSC)-Based Cellular Model of Dravet Syndrome." The word "Cell" was misspelled as "Call" as a result of a production error, for which the publisher apologizes. Because "Cell" is redundant with "Cellular," the authors requested that the latter be removed from the title. The title of the current version of the article, shown above, reflects these revisions.

doi: $10.1101 / \mathrm{sqb} .2018 .83 .038919$ 


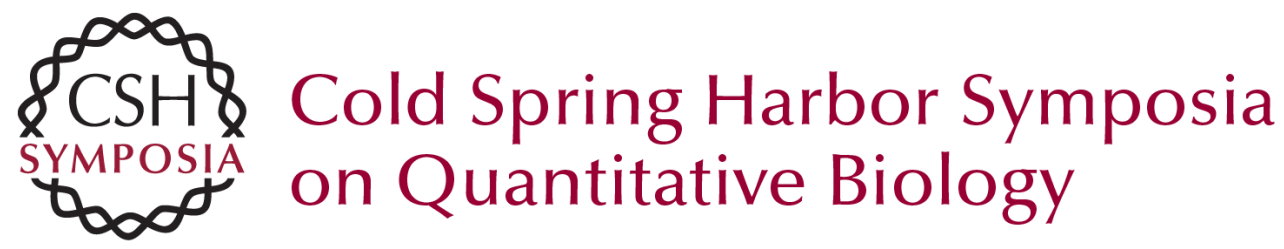

\title{
Erratum: Investigating the Therapeutic Mechanism of Cannabidiol in a Human Induced Pluripotent Stem Cell (iPSC)-Based Model of Dravet Syndrome
}

\author{
Yishan Sun and Ricardo E. Dolmetsch
}

Cold Spring Harb Symp Quant Biol 2018 83: originally published online August 1, 2019 Access the most recent version at doi:10.1101/sqb.2018.83.038919
Related Content Investigating the Therapeutic Mechanism of Cannabidiol in a Human Induced Pluripotent Stem Cell (iPSC)-Based Model of Dravet Syndrome
Yishan Sun and Ricardo E. Dolmetsch
Cold Spring Harb Symp Quant Biol UNKNOWN , 2018 83: 185-191

License

Email Alerting

Receive free email alerts when new articles cite this article - sign up in Service the box at the top right corner of the article or click here. 